\title{
Unprecedented recent warming rate and temperature variability over the east Tibetan Plateau inferred from Alpine treeline dendrochronology
}

\author{
Chunming Shi · Valérie Masson-Delmotte • \\ Valérie Daux $\cdot$ Zongshan Li $\cdot$ Matthieu Carré $\cdot$ \\ John C. Moore
}

Received: 4 July 2014 / Accepted: 14 October 2014 / Published online: 26 October 2014

(C) Springer-Verlag Berlin Heidelberg 2014

\begin{abstract}
Despite instrumental records showing recent large temperature rises on the Tibetan Plateau (TP), only a few tree-ring temperature reconstructions do capture this warming trend. Here, we sampled 260 trees from seven Alpine treeline locations across the southeast TP. Standardized tree-ring width chronologies of Abies squamata and Sabina squamat were produced following Regional Curve Standardization detrending. The leading principal component of these records is well correlated with the regional summer (JJA) minimum temperature (MinT) $\left(\mathrm{R}^{2}=0.47\right.$, $P<0.001,1953-2009)$. Hence we produce a regional summer MinT reconstruction spanning the last 212 years. This reconstruction reveals a long-term persistent warming trend, starting in the $1820 \mathrm{~s}$, at a rate of $0.45 \pm 0.09{ }^{\circ} \mathrm{C} /$ century (1820-2009). This trend is also detected since the 1820 s in the Asian summer MinT reconstruction produced by the PAGES $2 \mathrm{~K}$ project, with a very close warming rate
\end{abstract}

Electronic supplementary material The online version of this article (doi:10.1007/s00382-014-2386-z) contains supplementary material, which is available to authorized users.

C. Shi $\cdot$ J. C. Moore $(\bowtie)$

State Key Laboratory of Earth Surface Processes and Resource Ecology, College of Global Change and Earth System Science, Beijing Normal University, Beijing 100875, China

e-mail: john.moore.bnu@gmail.com

C. Shi

e-mail: chunming.shi@gmail.com

C. Shi $\cdot$ J. C. Moore

Arctic Centre, University of Lapland, 96101 Rovaniemi, Finland

V. Masson-Delmotte $\cdot$ V. Daux

Laboratoire des Sciences du Climat et de l'Environnement, UMR CEA-CNRS-UVSQ 8212, Institut Pierre Simon Laplace, Gif-sur-Yvette, France $\left(0.43 \pm 0.08{ }^{\circ} \mathrm{C} /\right.$ century, $\left.1820-1989\right)$. Our record also displays an enhanced multi-decadal variability since the midtwentieth century. The 1990s-2000s are the warmest of our whole record, due to the superposition of the gradual warming trend and decadal variability during this interval. The strongest decadal cooling occurs during the 1950s and the largest warming trend during the 1970s. The magnitude of warming from 1973 to 2003 was larger than the total warming trend from 1820s to 2009. Extreme events are also more frequent since 1950 . The pattern of multidecadal variability has similarities with the Atlantic multidecadal oscillation, suggesting common causality. CMIP5 historical simulations fail to capture both the magnitude and timing of this multi-decadal variability. The ensemble CMIP5 average produces a steady warming trend starting in the 1970s, which only accounts for about $60 \%$ of the observed warming trend during this period. We conclude that TP summer temperature could reflect a climate response to increased greenhouse gas concentrations, however modulated by multi-decadal variations common with the Atlantic sector.

V. Daux

Université de Versailles - Saint Quentin, Versailles, France

Z. Li

State Key Laboratory of Urban and Regional Ecology, Research

Center for Eco-Environmental Sciences, Chinese Academy of Sciences, Beijing 100085, China

M. Carré

UM2-CNRS-IRD, Institut des Sciences de l'Evolution de Montpellier, Université Montpellier 2, CC065, Pl. Eugène Bataillon, 34095 Montpellier, France 


\section{Introduction}

The Tibetan Plateau (TP), the highest and largest plateau in the world, has profound effects on the Asian climate system (Manabe and Broccoli 1990). During recent decades, instrumental temperature data have revealed that TP has been experiencing earlier and faster warming than low altitude regions at the same latitude (Liu and Chen 2000), with the strongest changes observed at the highest elevations of TP (Chen et al. 2003; Qin et al. 2009; Wei and Fang 2013). This fact is associated with concerns about accelerating regional glacier retreat (Yao et al. 2004, 2012), changing patterns of Asian Summer Monsoon precipitation (Wang et al. 2008), and potential threats for water resources and food security in surrounding areas (Piao et al. 2010).

Detection and attribution studies depict an anthropogenically forced component of Asian warming since the 1960s (Chapter 10 in IPCC AR5, WG1, 2013). However, such methods cannot be applied for TP, because the short instrumental records can't fully capture the spectrum of natural and human induced variability of TP temperature on multidecadal and longer time scales. Meteorological information is restricted to the location of weather stations, mostly in inhabited, low elevation areas and from the mid-twentieth century onwards. Longer records are critical for distinguishing climate change signal from natural variability and attributing the change to natural and/or anthropogenic factors. Temperature records from high elevations can also be used to assess the temperature lapse rate stability over time, which would have implications for the evaluation of climate model outputs and downscaling methods.

One way to address these issues is by comparing simulations of past climate with proxy climate records. Historical simulations from the Coupled Model Intercomparison Project Phase 5 [CMIP5; (Knutson et al. 2013)], IPCC Fifth Assessment Report (Chapter 10 in IPCC AR5, WG1, 2013), and Northern Hemisphere temperature reconstructions (Briffa et al. 2001, 2004; Esper et al. 2002; Oerlemans 2005; D'Arrigo et al. 2006; Ljungqvist et al. 2012) all show hemispheric and global warming trends from the nineteenth to twentieth century. The PAGES $2 \mathrm{~K}$ project (PAGES 2k Consortium 2013) combined more than 200 tree-ring chronologies from Asia and also reported a strong warming trend of summer (JJA) mean temperature of continental Asia since the 1820s (PAGES 2k Consortium 2013).

Climate records from the high elevation parts of the Tibetan Plateau are, so far, only available from ice core and tree-ring records (Liang et al. 2009; Thompson et al. 1997). Since the quantitative interpretation of the $\delta^{18} \mathrm{O}$ signal in ice cores as a temperature record remains challenging (Yao et al. 2013), we focus here on tree-ring width (TRW) records. Most TRW-based temperature reconstructions produced for TP have not captured any significant warming trend since the nineteenth century (Liang et al. 2008, 2009; Yang et al. 2010a, b; Cao et al. 2012; Duan et al. 2012; Lv and Zhang 2013; He et al. 2013). However, one recent TRW study from the Western Himalayas (Yadav et al. 2011) reported large centennial temperature variability, with cooling in the eighteenth and nineteenth centuries and warming since the 1890 s, while another study from the northern TP suggested the onset of a warming trend started in the 1820s (Zhu et al. 2008).

The use of tree ring data for past temperature reconstructions is associated with a number of challenges, such as the preservation of low frequency climate signals while removing age growth effects from the record (Cook et al. 1995). Other issues can arise from the multiple factors which affect tree growth, especially non-temperature climatic factors such as water stress (Wilmking et al. 2004), or the fertilization effect of increasing atmospheric $\mathrm{CO}_{2}$ concentrations (Briffa et al. 1998; Knapp et al. 2001; Norby et al. 2005; Saxe et al. 1998). The mean squared correlation coefficients of existing TP standard TRW chronologies and instrumental temperature records is 0.36 (Liang et al. 2008; Zhu et al. 2008; Yang et al. 2010a, b; Cao et al. 2012; He et al. 2013). However, detrended records (residual chronologies) have lower correlations (e.g. $\mathrm{R}^{2}=0.27$, Lv and Zhang 2013). Therefore a large fraction of common variance between TRW indices and instrumental temperature records arises from the coincidence of multi-decadal trends, rather than a causal control of tree growth by seasonal temperature. Moreover, only a few of the abundant TP TRW based temperature reconstructions (Liang et al. 2008, 2009; Yang et al. 2010a, b; Duan et al. 2012; Cao et al. 2012; Lv and Zhang 2013; He et al. 2013), exhibit centennial temperature variability (Zhu et al. 2008; Yadav et al. 2011). Flat temperature reconstructions may arise from inappropriate sampling or detrending methods. The regional curve standardization (RCS) has been shown to be a robust method of extracting low frequency climate signals (Esper et al. 2003; D'Arrigo et al. 2006), justifying the choice of this methodology hereafter.

Many existing TRW based temperature reconstructions were made using trees growing well below their altitudinal limit. But it is at the Alpine treelines where xylogenesis and radial growth are most strongly limited by low temperature (Jobbagy and Jackson 2000; Korner 2003), and not by the scarcity of photosynthetic products, because higher concentrations of photosynthetic products (non-structural carbohydrates) are observed for trees growing in colder climate with higher elevation (Hoch et al. 2002; Fajardo et al. 2013). Furthermore, the temperature-limiting processes associated with carbon fixation (that is incorporation of the carbon into tree cells) most likely occur during the night time (Korner 1998; Swidrak et al. 2011). Therefore, growth at the treeline is likely more controlled by temperature than 
by photosynthesis. Recent studies have shown that environmental signals such as the increasing atmospheric $\mathrm{CO}_{2}$ concentration are unlikely to affect growth patterns in the narrow Alpine treeline band (Salzer et al. 2009). Hence, temperature reconstructions based on trees sampled below their treelines, could in fact be contaminated by climate signals other than temperature (Jobbagy and Jackson 2000; Makinen et al. 2002), or by unstable tree growth-climate responses (Shi et al. 2010; Zhang and Wilmking 2010; Gao et al. 2013). These considerations motivate a tree sampling strategy restricted to the TP Alpine treeline.

In this study, we use new TRW data from seven Alpine treelines (species Abies squamata and Sabina squamat) along a South East TP transect. After correction for biological trends using RCS, standard TRW chronologies are combined using principal component analysis (PCA). We used linear correlation analyses to calibrate the relationships between the first leading PC and regional instrumental data. The resulting summer minimum (night) temperature reconstruction spanning the last 212 years is described and compared with earlier reconstructions (notably the PAGES $2 \mathrm{~K}$ reconstruction) and with results from CMIP5 historical climate simulations. The mechanisms responsible for the observed decadal variability are investigated, with a focus on the Atlantic multidecadal oscillation (AMO).

\section{Material and method}

\subsection{Study area}

The tree-ring samples used in this study are A. squamata growing at Alpine treelines in the Tibetan Autonomous Prefecture of Garzê, southeast Tibetan Plateau. Garzê is in the transition region from TP to the Sichuan Basin, with elevations ranging from around 1,000-7,556 m. Samples of $A$. squamata were collected from 6 sites in the counties of Batang (BT), Derong (DR), Baiyu (BY), Seda (SD), Xinlong (XL), and Daofu (DF) (Fig. 1). These data are combined with one recent chronology of Sabina squamat obtained from nearby Miyaluo (MYL) Alpine treeline, which showed a close link with regional summer temperature (Li et al. 2011).

All our sampling sites are remote from human habitation and show no evidence of direct human activity. Meteorological observations are available from nine stations (Batang, Daocheng, Daofu, Dege, Ganzi, Ma'erkang, Seda, Litang and Xinlong; Fig. 1) located at elevations from 2,589 to 3,950 m, which began operating between 1953 and 1961. Annual mean temperature records at each station are highly coherent; the leading principal component (PC1) of the mean annual temperatures explained $85 \%$ of total variance. The regional mean annual temperature is $3.7^{\circ} \mathrm{C}$ and the mean annual precipitation $683 \mathrm{~mm}$ (Fig. 2a), with about $57 \%$ of precipitation falling between June and October. Summer precipitation is controlled both by East Asian Summer Monsoon and by South Asian Summer Monsoon (Wang and Linho 2002).

The mean elevation of the nine meteorological stations is $3007,914 \mathrm{~m}$ lower than that of our sampling sites. The mean inter-series correlation coefficients are 0.66 for summer (June-August) mean temperatures, 0.71 for summer minimum temperatures, and 0.40 for summer precipitation (Fig. 2b-d). We therefore conclude that there has been a strong common temporal variability of summer temperature over a large range of elevations during the instrumental period. Summer mean and minimum temperatures show a decreasing trend from the 1950s to the 1970s, followed by an increasing trend since the mid-1970s (Fig. 2b, c). These recent (1973-2003) summer warming trends are strongest at high elevation (Supplementary Table 1). The magnitude of inter-annual variability of summer mean and minimum temperature is comparable (with mean standard deviations of 0.59 and $0.64{ }^{\circ} \mathrm{C}$, respectively). The regional average temperature extracted from the gridded CRU 3.1 dataset exhibits the same patterns of variability (Fig. 2b, c) as the regional series. In contrast, summer precipitation shows no significant multi-decadal trend over the instrumental period (Fig. 2d).

\subsection{Tree ring sampling, processing and chronology construction}

Abies squamata is the dominant Alpine treeline species in Garzê, usually growing on shaded slopes at high elevation. The heights of the trees selected for this study range from 6 to $25 \mathrm{~m}$. At each site, 40 trees in open canopy with straight stems and no sign of damage or internal rotting were selected. Two cores per tree were taken with an increment borer (inner diameter $5.14 \mathrm{~mm}$ ) at opposite sides of each tree. This procedure was repeated until at least 2 cores reached the pith of each tree. During this study, we sampled six sites (BT, BY, DF, DR, SD and XL in Fig. 1), and this database is supplemented using the published Miyaluo record from Li et al. (2011) (MYL in Fig. 1). Detailed information on these sampling sites is listed in Table 1.

Core samples were air dried and polished with progressively finer sandpaper until rings were clearly visible. Tree-ring widths (TRW) were measured using the Lintab ${ }^{\circledR}$ system with a resolution of $0.01 \mathrm{~mm}$, and cross-dated by visual inspection under microscope. The cross-dated treering series were quality-checked using the COFECHA software (Holmes 1983). TRW of cores from the same tree were averaged, and ring widths of all trees from the same site were combined to form a standard chronology with the software toolkit "dplR" (Dendrochronology Program Library in R language) using the RCS detrending method (Briffa et al. 1992; Cook et al. 1995). The ring-width 
Fig. 1 Sampling sites. The right bottom corner insert shows the TP (grey shading depicting elevation above 3,000 $\mathrm{m}$ ) and the sampling region (black rectangle). Within the sampling region (main figure), filled red circles depict our sampling sites (see text for details), and filled triangles show the position of meteorological stations. Black circles show the position of nearby chronologies used in the PAGES $2 \mathrm{k}$ reconstruction, labeled Asi_38 to Asi_42 and Asi_79 to Asi_83 (PAGES 2k project)

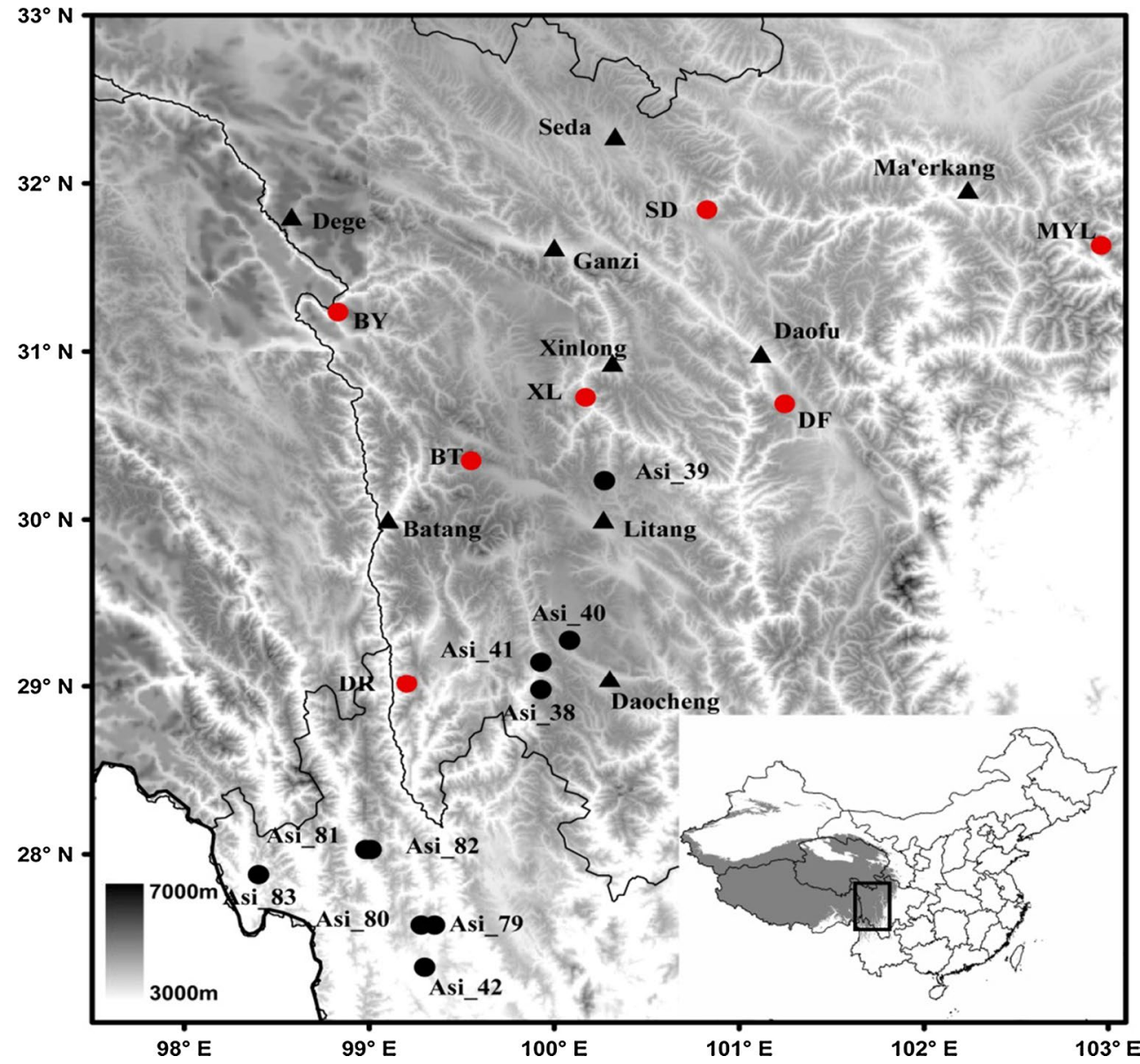

measurements of each site are aligned by biological age (with pith offsets estimate for all samples), and the Tukey's Biweight Robust Mean (excluding outliers exceeding \pm 6 standard deviations) of ring width for each biological age were calculated and smoothed using an n-year spline where the frequency response is 0.50 at a wavelength of $10 \%$ of the maximum cambial age to form a RCS curve. Each ring measurement is then divided by the smoothed RCS curve value of the same ring age to create a TRW index, the mean of all tree TRW indexes is the standard chronology of each site. Only portions of chronology with a replication of at least five trees are considered further here. Twenty-five year moving expressed population signal (EPS) were calculated for each chronology (Grey lines in Fig. 3). The missing ring rate is less than $0.1 \%$, and the mean ring widths for each site are shown in Table 1.

\section{Results}

\subsection{Inter-chronology variability and PCA analysis}

All TRW chronologies are shown in Fig. 3a-g (black lines), with a 30-year fast fourier transform (FFT) low-pass filter.
Over the time interval 1860-2009, 3 chronologies show significant $(P<0.01$ against white noise) increasing linear trends (BY, DF, DR), while two other chronologies depict, by contrast, significant $(P<0.01)$ decreasing trends (MYL, BT). Strong trends are observed from 1860 to 2010 at the DR and BT sites, but with opposite signs, in contrast with nearby meteorological records which show similar summer temperature trends (Fig. 2b, c). These trends are robust against changing the flexibility of the smoothing spline used in the RCS detrending. The mean inter-chronology correlation coefficient for standard chronologies is 0.19 (Supplementary Table 2). The mean inter-chronology correlation coefficients for the 30 years and 3 years high pass FFT filtered chronologies are 0.21 and 0.34 (Supplementary Table 2).

We excluded the "chronology slope problem" (Briffa and Melvin 2011; Melvin and Briffa 2014) as a cause of the reverse slopes of BT and MYL by applying signal-free RSC detrending using software RCSigFree. The BT trees are much older than trees from other sites (Table 1), and old trees are less sensitive to temperature variability and have shorter growing seasons than young alpine treeline trees ( $\mathrm{Li}$ et al. 2013; Rossi et al. 2008a). However an ageeffect can't explain the negative growth trend of BT. The 

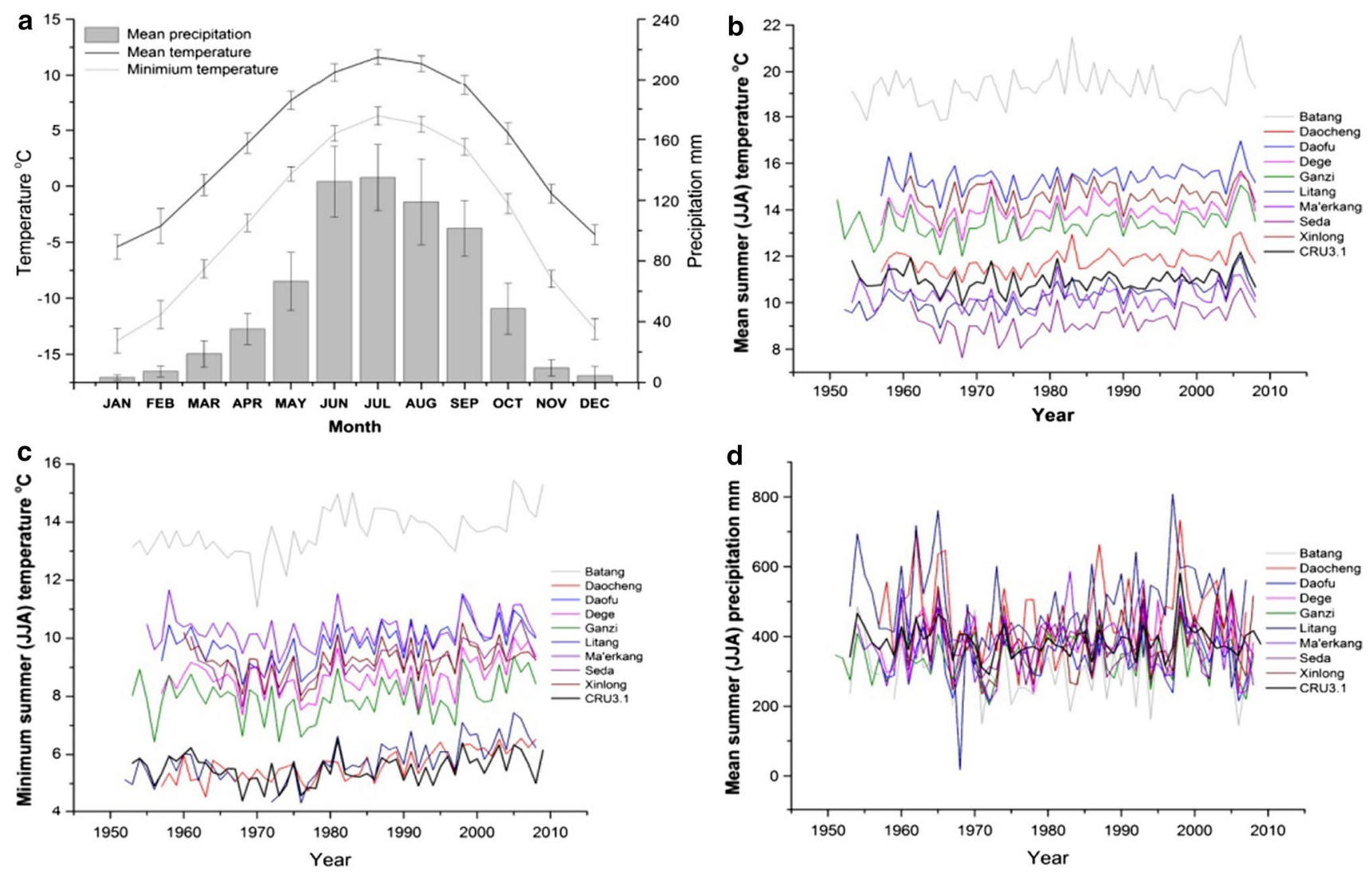

Fig. 2 a Regional climatology extracted from the CRU 3.1 dataset (data averaged over $28^{\circ} \mathrm{N}-33^{\circ} \mathrm{N}$ and $98^{\circ} \mathrm{E}-103^{\circ} \mathrm{E}$ from years 1953 to 2009). Grey bars mean monthly precipitation, black line mean monthly temperature, grey line mean minimum monthly precipitation.

MLY chronology is based on a species different from the others (Table 1), and a species-specific study is still lacking in this area. However MYL does have a good correlation with summer temperature ( $\mathrm{Li}$ et al. 2011). The inter-chronology correlation of 3 years high pass filtered chronologies $(0.34)$ is higher than that of both the standard and the 30 years high pass filtered chronologies (Supplementary Table 2), which suggests that diverse long term local environment effects may be present in addition to a common regional temperature signal, and reduced the inter-chronology consistency. Slow depletion of soil nutrients could produce the observed trend of BT (Thebault et al. 2014), but confirmation of causation need much more detailed field investigation in future studies.

To extract the climate signal common in our chronologies, we performed a PCA. The leading PC (PC1), explains $34 \%$ of total variance (Fig. $3 \mathrm{~h}$ ), the loadings of each chronology are listed in Table 1. PC1 shows an overall increasing trend since the $1820 \mathrm{~s}$. The robustness of PC1 was checked using a jack-knife method by removing one chronology each time and recalculating PC1 with the remaining 6 chronologies. This sensitivity test suggests that all PC1s
The magnitude of inter-annual variability calculated from 1953-2009 is represented using vertical error bars for each dataset. b-d Mean summer (JJA) temperature, minimum summer temperature and summer precipitation recorded in meteorological stations shown in Fig. 1

show similar trends with a mean correlation coefficient of 0.90 (Supplementary Fig. 1). Excluding BT slightly raises this correlation to 0.92 . The PC1 of all chronologies loads the BT chronology by only 0.02 (Table 1 ), hence its impact on PC1 is negligible. The confidence interval of PC1 for each year is taken as the maximum minus minimum values from the jack-knife test.

\subsection{Statistical analyses of linear relationships}

between TRW chronologies and local to regional climate data

A bootstrap correlation was conducted using the Dendroclim 2002 software (Biondi and Waikul 2004) to identify the key factors controlling tree growth. We used meteorological data from the station closest to each tree ring site, and considered minimum monthly temperature (MinT), mean monthly temperature (MeanT) and monthly total precipitation (TotalP). Due to the different starting years of the meteorological stations (Table 1), the number of years used for statistical analyses varies from 48 to 56 years. 


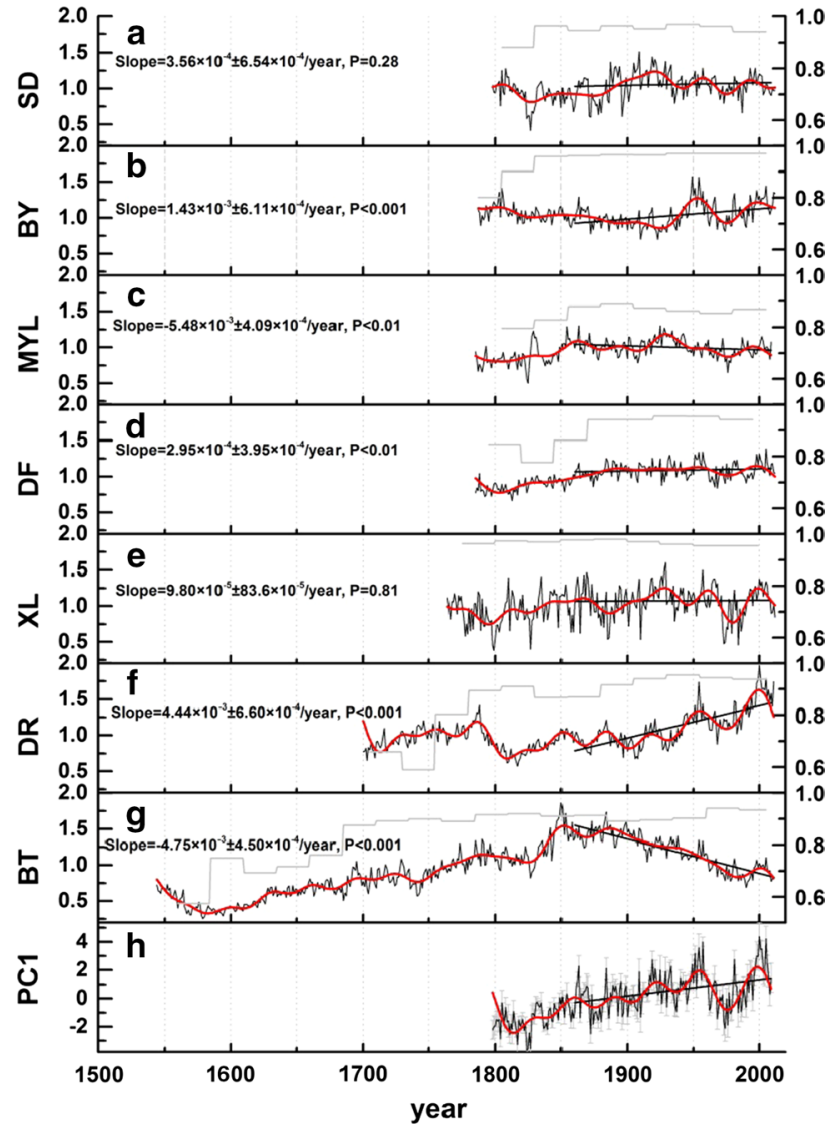

Fig. 3 Standardized TRW chronologies (after RCS detrending) and PC1 of the seven chronologies (34\% of the total variance). Red lines show a 30 year low-pass filter. Black lines are linear trends calculated for each chronology from 1860 to 2009. Grey lines are the moving expressed population signal (EPS) value of each chronology (right axis). The error bar on PC1 is the interval (maximum minus minimum value of each year) of jack-knife test shown in supplementary Fig. 2

Figure 4a shows that highest monthly correlation with MinT is mostly observed during summer months (June to August). Chronologies from BY, DF, XL, MYL and PC1 are significantly correlated with summer (JJA) averaged
MinT $(P<0.001)$. While chronology BT has not shown any significant correlation with summer MinT. The strongest correlation is found between PC1 and summer averaged CRU MinT (1953-2009), which explains almost half of the variance of the signal $\left(\mathrm{R}^{2}=0.47, \mathrm{n}=57, P<0.001\right)$.

Exploring correlations between TRW records and MeanT leads to similar results as obtained with MinT, albeit with lower correlation coefficients. As a result, we only observe significant correlations $\left(R^{2}=0.29\right.$ and $0.19)$ between MYL and DF records and summer MeanT (Fig. 4b, $P<0.001$ ). We cannot detect any significant correlation between monthly or seasonal precipitation time series and the chronologies or the PC1 (Fig. 4c). The close link between alpine tree growth and summer minimum temperature supports the temperature limiting theory of radial tree growth at high elevation: cambial activity and xylem cell differentiation starts and ends when crossing a certain temperature threshold, regardless of the tree species (Rossi et al. 2007, 2008b). For alpine trees, a minimum value of the night temperature is required for radial growth during the warm season (Korner 1998), that is July-August in our study area (Fig. 4). The temperature limiting effect was also observed in a cambial phenology study on the southeastern TP (Li et al. 2013), and by dendrochronology near our study region ( $\mathrm{Li}$ et al. 2011).

Figure 5a displays a map of correlation coefficients between PC1 and CRU 3.1 summer MinT. The results show that the correlation between PC1 and summer MinT extends north and west to a large area spanning $15^{\circ}$ of latitude and $40^{\circ}$ of longitude, extending from the Himalayas into mainland China and Mongolia (Fig. 5a). The robustness of this result is confirmed when using linearly detrended PC1 and CRU MinT data (Fig. 5b).

Based on these correlations, we performed a regression analysis between TRW PC1 and CRU 3.1 regional summer MinT averaged over the region $28-33^{\circ} \mathrm{N}, 98-103^{\circ} \mathrm{E}$ (Fig. 6a). Leave-one-out cross verification was conducted, and a RE (reduction of error statistic) of 0.44 supports the robustness of the reconstruction. Repeating the regression
Table 1 Location (latitude and longitude), elevation, number of successfully cross-dated trees at each site, mean and standard deviation of the ring-width series during the overlapping period (1798-2011), species name, time span of nearby weather stations and each chronology (with at least five trees for a given year), and loading of each chronology to the leading principal component shown in Fig. $3 \mathrm{~h}$

\begin{tabular}{|c|c|c|c|c|c|c|c|c|c|c|}
\hline Sites & LAT N & LON E & Elev. (m) & N. tr. & $\mathrm{RW}(\mathrm{mm})$ & STD & Species & Sta. span & Tr. span & Loading \\
\hline BT & $30^{\circ} 21^{\prime}$ & $99^{\circ} 33^{\prime}$ & 4,160 & 38 & 1.17 & 0.79 & Abies squamata & 1953-2009 & $1544-2011$ & 0.02 \\
\hline BY & $31^{\circ} 14^{\prime}$ & $98^{\circ} 50^{\prime}$ & 4,012 & 38 & 1.49 & 0.8 & Abies squamata & 1957-2009 & $1787-2012$ & 0.31 \\
\hline DF & $30^{\circ} 41^{\prime}$ & $101^{\circ} 15^{\prime}$ & 4,113 & 39 & 1.15 & 0.57 & Abies squamata & 1957-2009 & $1785-2012$ & 0.52 \\
\hline DR & $29^{\circ} 1^{\prime}$ & $99^{\circ} 12^{\prime}$ & 4,221 & 38 & 0.87 & 0.61 & Abies squamata & 1957-2009 & $1700-2011$ & 0.47 \\
\hline SD & $31^{\circ} 50^{\prime}$ & $100^{\circ} 50^{\prime}$ & 3,671 & 35 & 1.28 & 0.75 & Abies squamata & 1961-2009 & 1798-2012 & 0.39 \\
\hline MYL & $31^{\circ} 38^{\prime}$ & $102^{\circ} 14^{\prime}$ & 3,750 & 38 & 0.52 & 0.60 & Sabina squamat & 1955-2009 & $1785-2012$ & 0.34 \\
\hline XL & $30^{\circ} 44^{\prime}$ & $100^{\circ} 10^{\prime}$ & 3,522 & 34 & 0.95 & 0.47 & Abies squamata & 1960-2009 & 1764-2012 & 0.39 \\
\hline
\end{tabular}


Fig. 4 Bootstrap correlation coefficients between TRW chronologies/PC1 and monthly local climate indices from May of previous year to October of current year. For TRW, correlations are reported with respect to the closest meteorological station. For PC1, correlation coefficients are calculated with respect to the average regional temperature $\left(\mathrm{N} 28-33^{\circ} \mathrm{E}\right.$ 98-103 ${ }^{\circ}$ ) from CRU 3.1 data. a Minimum temperature; $\mathbf{b}$ mean temperature; c precipitation. Stars show results which pass a $P<0.001$ significance test

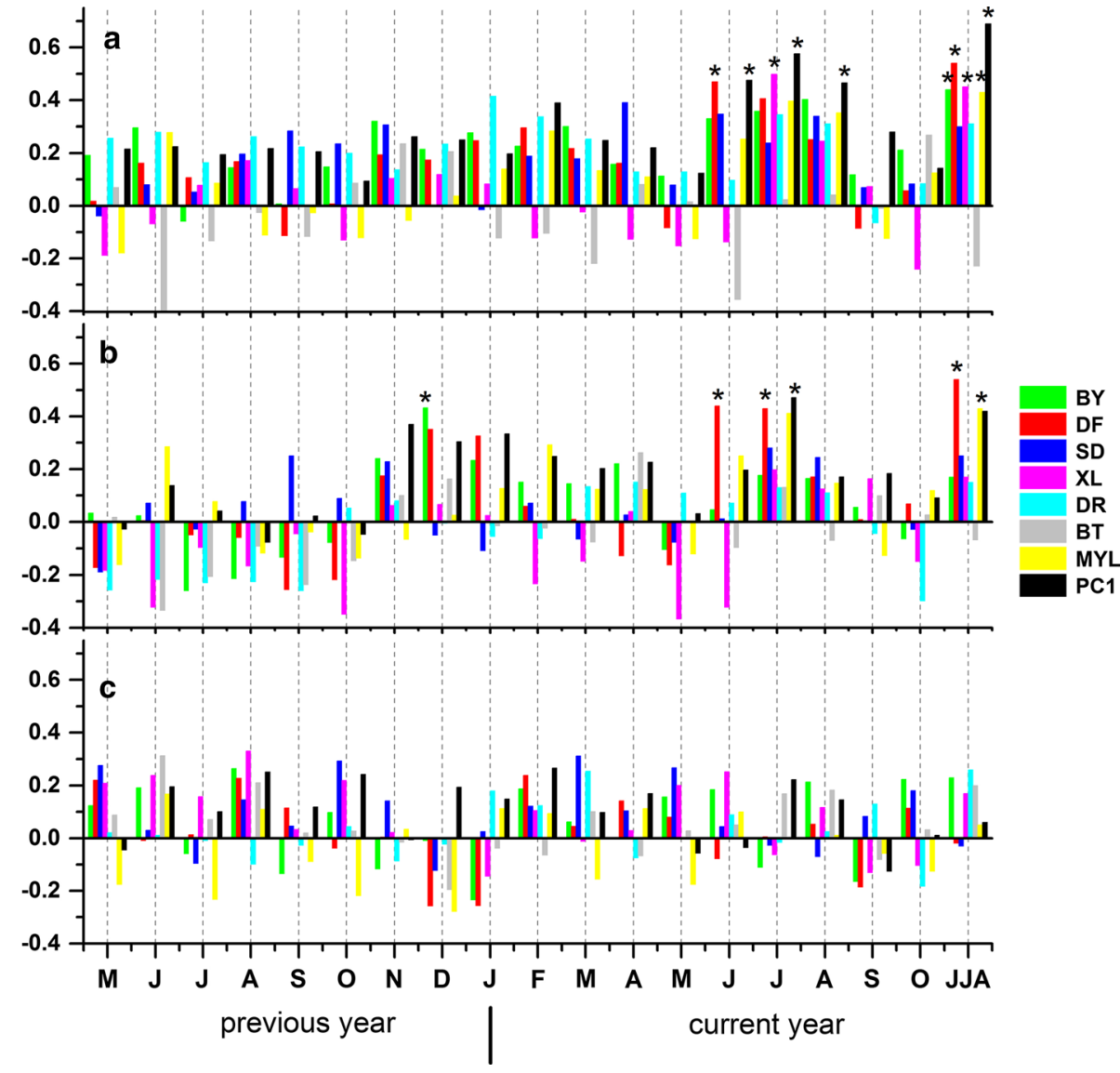

analysis using the triangle detrended PC1 method (this method is suitable for short records: the trend at year $\mathrm{n}$ is $\left.0.25 \times P C 1_{n-1}+0.5 \times P C 1_{n}+0.25 \times P C 1_{n+1}\right)($ Fig. 6b) leads to a slight decrease in the percentage of variance explained $\left(\mathrm{R}^{2}=0.40, P<0.001\right)$, with a higher slope $(0.37$ against $0.27{ }^{\circ} \mathrm{C} /$ unit). The consistent sensitivity of PC1 to temperature at inter-annual and longer time scales in instrumental period supports our reconstruction strategy.

\subsection{Regional summer MinT reconstruction and associated uncertainty}

Using the methodology described in Sect. 3.2, we can use our TRW data to quantify changes in regional summer MinT from 1798 to 2009 (Fig. 7, black line). The uncertainty associated with the reconstruction, displayed in grey, was estimated using a Monte Carlo 2-fold cross validation method. The 1953-2009 instrumental time series (MinT) and the proxy time series (TRW) were randomly divided in two halves. Each half was used to calculate a linear calibration model and validated with the other half, yielding 57 error values. The 2.5 and $97.5 \%$ thresholds of the probability density function of the error population after 1,000 iterations were -0.86 and $0.83{ }^{\circ} \mathrm{C}$. These values define the $95 \%$ confidence interval of the temperature reconstructions. The error calculation does not consider the decreasing number of trees back to the onset of the reconstruction, but most chronologies show an expressed population signal (EPS) value exceeding 0.85 in the 1800-2009 interval (Fig. 3), which implies adequate replication for climate reconstruction.

The reconstructed summer MinT displays a centennial warming trend (1820-2009) (green line in Fig. 7a) with a slope $=0.45 \pm 0.09{ }^{\circ} \mathrm{C} /$ century $\left(\mathrm{R}^{2}=0.34, P<0.001\right)$, and an overall temperature rise of $0.86 \pm 0.1{ }^{\circ} \mathrm{C}$. The strongest warming rates of summer MinT occurs over the 1973-2003 interval, with rates of $0.41 \pm 0.13{ }^{\circ} \mathrm{C} /$ decade $\left(\mathrm{R}^{2}=0.57, \mathrm{n}=31, P<0.001\right)$ for the reconstruction and $0.37 \pm 0.24{ }^{\circ} \mathrm{C} /$ decade $\left(\mathrm{R}^{2}=0.23, \mathrm{n}=31\right.$, $P<0.05)$ for observations. From 1973 to 2003, summer MinT increased by $1.27 \pm 0.23{ }^{\circ} \mathrm{C}$ in our reconstruction and by $1.11 \pm 0.25{ }^{\circ} \mathrm{C}$ in CRU data, which is larger than the reconstructed overall warming for the whole of the last 190 years. The warmest decades in summer MinT are the 1990s-2000s.

These variations of recent decades, well known from TP instrumental data, have contributed to glacier melting and hydrological changes (Kang et al. 2010; Yao et al. 2012; Wang et al. 2013c; Yang et al. 2014). Physiological studies, monitoring cambial activity and growing length in 
Fig. 5 Map of the correlation coefficient between $\mathrm{PC} 1$ and gridded CRU 3.1 MinT, filtered for results which are significant at $P<0.01$, a using the raw datasets; $\mathbf{b}$ using linearly detrended $\mathrm{PC} 1$ and detrended CRU 3.1 MinT (1953-2009). Black rectangles show the sampling region
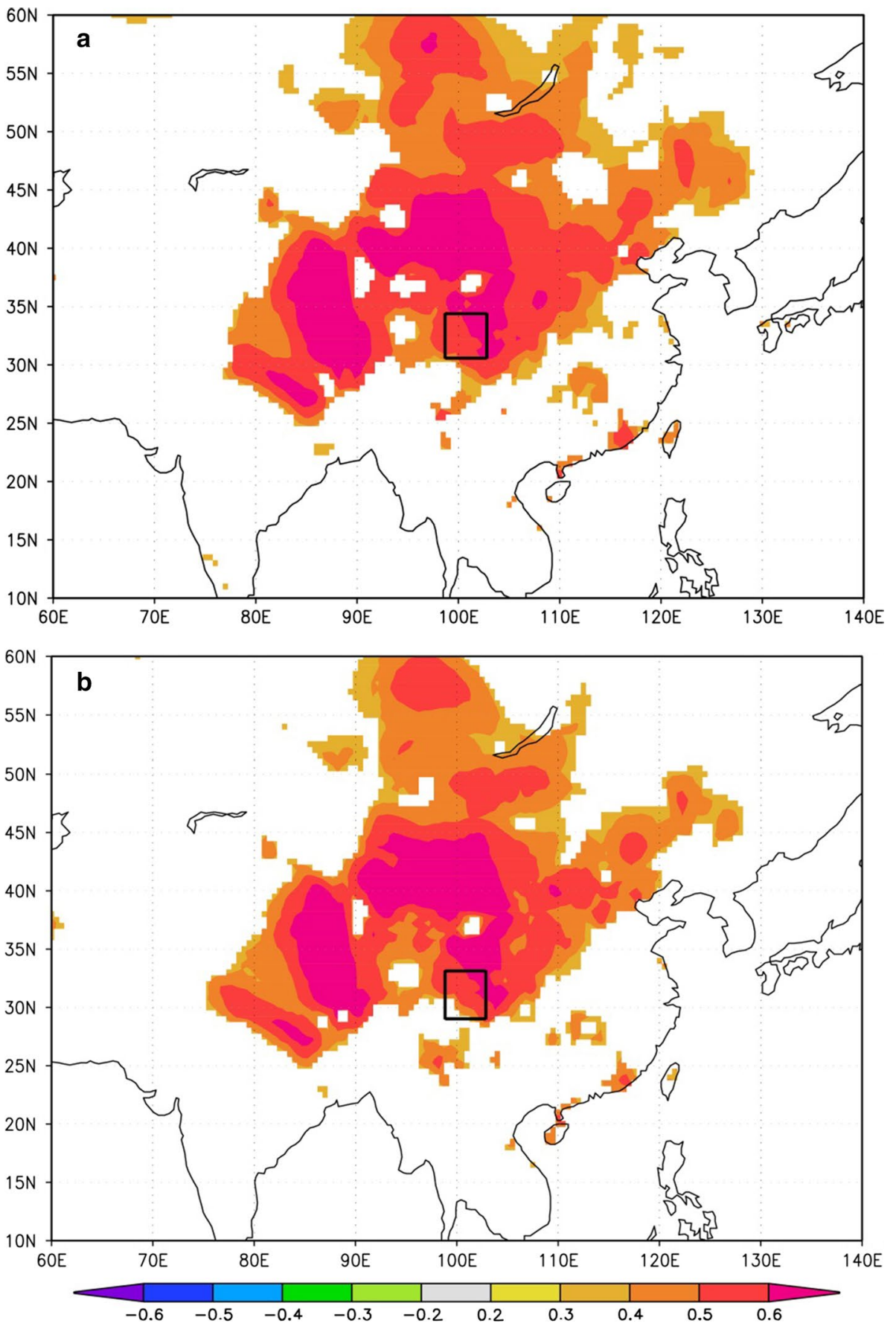

particular, are still scare for alpine treeline trees on TP $(\mathrm{Li}$ et al. 2013). Dendrochronology studies show that warming has significantly increased population density and growth rate of Alpine treelines trees, but has little impact on the altitude changes of Alpine treelines, for which no clear explanation has been proposed (Liang et al. 2009, 2011).

The largest cooling trend in the reconstruction is from 1953 to 1975 (slope $=-0.43 \pm 0.17{ }^{\circ} \mathrm{C} /$ decade, $\left.\mathrm{R}^{2}=0.50, \mathrm{n}=23, P<0.001\right)$. The largest cooling trend in the regional CRU data also occurs during this period (slope $=-0.45 \pm 0.35{ }^{\circ} \mathrm{C} /$ decade, $\mathrm{R}^{2}=0.26, \mathrm{n}=23$, $P<0.05)$. It is then offset by the subsequent 1973-2003 warming. As a result there is no net significant trend over the whole instrumental period. Prior to the instrumental period, our reconstruction depicts cold intervals in the 1820s, 1870s-1880s, and 1970s-1980s, and warm intervals in the 1910s, 1950s and 1990s-2000s (marked with transparent green and red bars in Fig. 7a). We define extreme summer MinT as years exceeding 1.5 standard deviations above or below the 30-year filtered trend. Extreme warm 

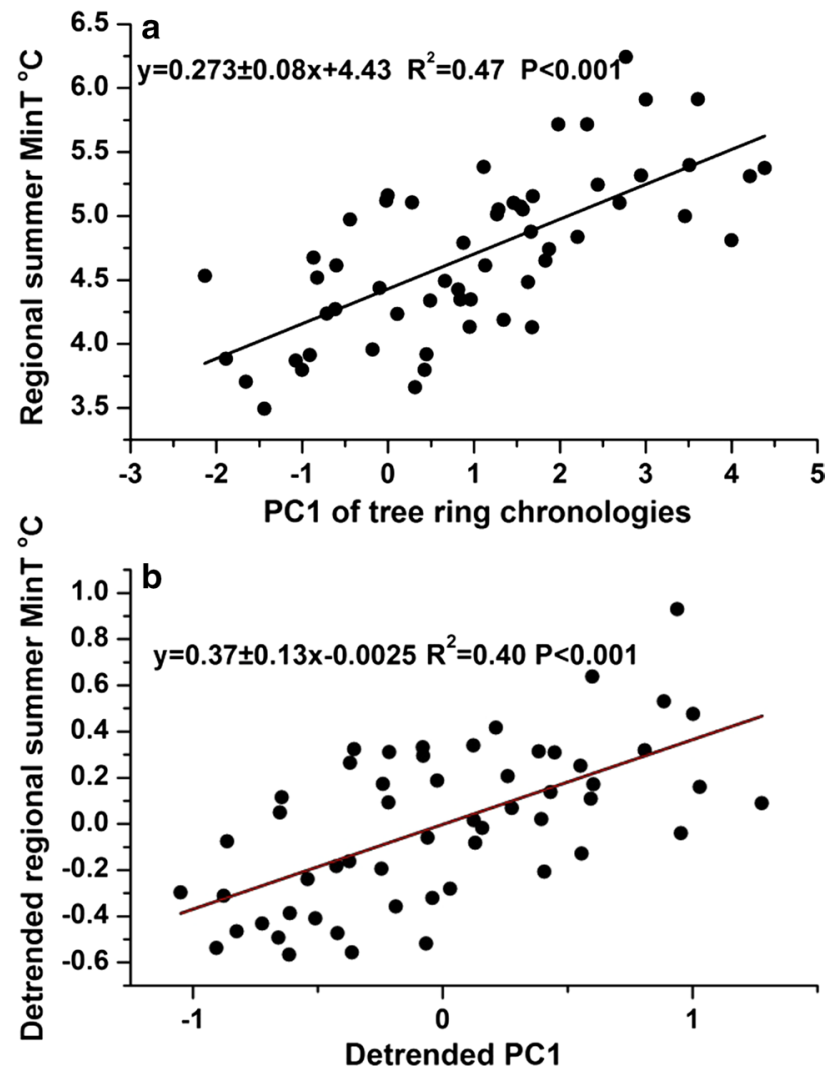

Fig. 6 Linear calibration of PC1 and CRU 3.1 JJA MinT averaged over N 28-33 ${ }^{\circ}$ E $98-103^{\circ}$ (a) raw PC1 and summer MinT (b) spline detrended summers are then 1863, 1884, 1909, 1957, 1981 and 2009, and extreme cold summers are 1864, 1872, 1886, 1930, 1952, 1968 and 1995. Six out of the 12 extreme years are in the instrumental period, and all except 1957 were observed to be extremely warm or cold in instrumental data as well. The 30-year moving standard deviation of MinT also reaches its largest value during the instrumental period (Fig. 7b).

\section{Relationship with North Atlantic multi-decadal variability}

Our reconstructed summer MinT is significantly correlated with sea surface temperature (SST) in the North Atlantic averaged from January to May $(P<0.01$, after linearly detrending both records, Supplementary Fig. 2). We compared the multi-decadal variability of our reconstruction with AMO based on the ERSST data (Extended Reconstructed Sea Surface Temperature, van Oldenborgh et al. 2009). The 30-years FFT low-pass filtered MinT and

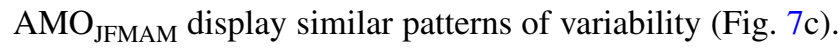
Before the 1970s, the AMO leads MinT, and the coherency was poor in the 1920s and 1940s. Post 1970s, AMO variation lagged MinT.

The close link between AMO and European temperatures is well known (Sutton and Hodson 2005; Sutton and Dong 2012). Several studies have reported coherency
Fig. 7 a Summer (JJA) MinT reconstruction (thin black line) and CRU data (red); 30 years FFT low pass filter of the reconstruction (thick blue line), thin blue lines are \pm 1.5 standard deviation based on the 30 years trend; $95 \%$ confidence interval of the reconstruction (grey shading). The green line shows the linear trend of the temperature reconstruction from 1820 to 2009 . The transparent green and red bars highlight the three coldest and three warmest 30 -year periods in the whole reconstruction b 30-year moving standard deviation of reconstructed MinT; c 30-year FFT filtered MinT and Atlantic Multidecadal Oscillation (AMO) index (van Oldenborgh et al. 2009)

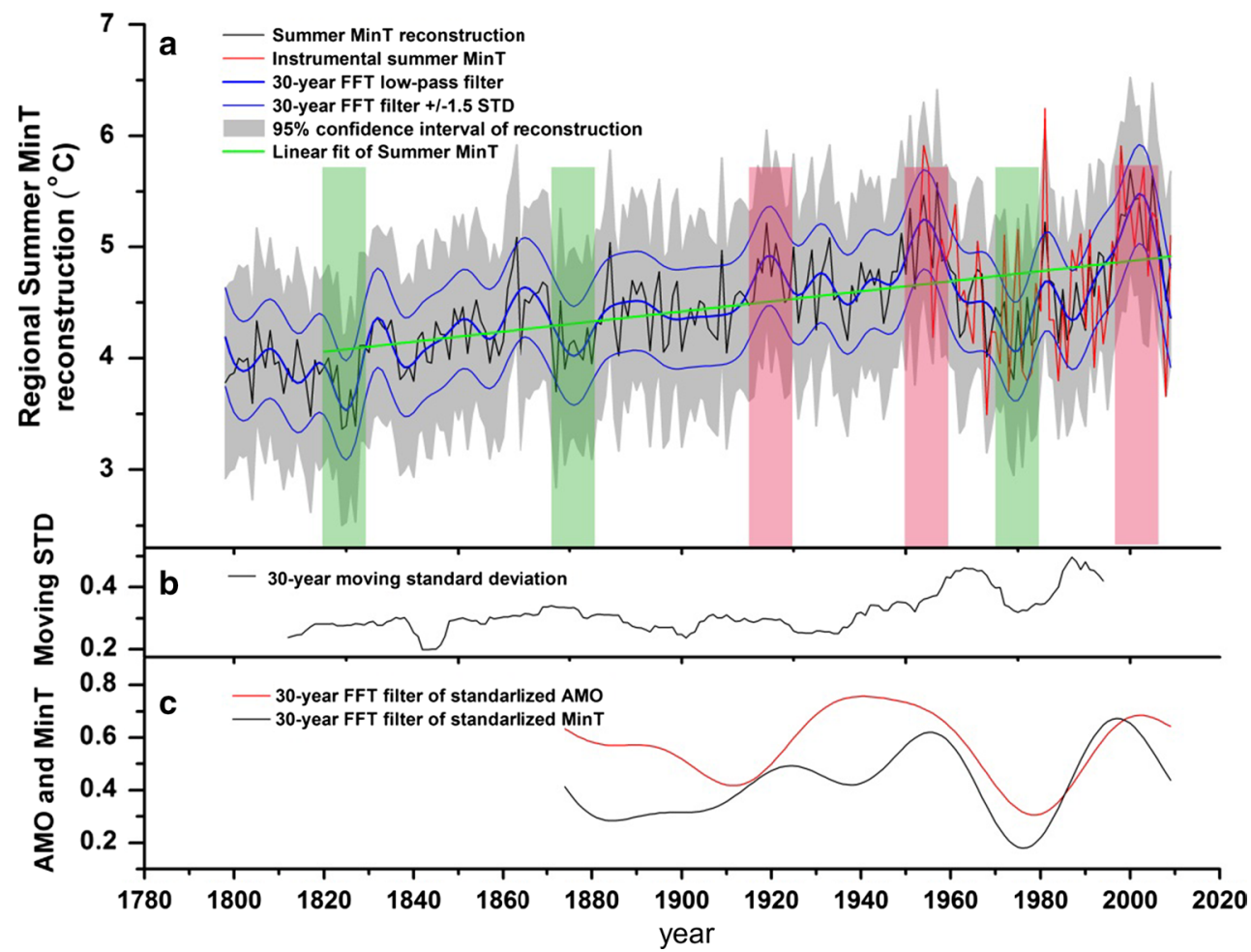


between Asian temperature reconstructions and AMO multi-decadal variations during the last millennium (Wang et al. 2013a, b). While we found that the summer MinT of our study may be modulated by AMO multi-decadal variation prior to the 1970s, the link between the two signals is subsequently weak and ambiguous. The mechanisms producing the connection may involve a propagation of the direct SST signal through Rossby waves (Sun et al. 2008), as well as an indirect effect on the monsoon (Wang et al. 2013a).

\section{Comparison with PAGES 2K and other reconstructions}

The PAGES $2 \mathrm{~K}$ program gathered 229 tree-ring chronologies to produce a reconstruction of summer (JJA) Asian MinT variability over the last millennium. This temperature reconstruction shows a large warming trend beginning in the 1820s (Fig. 8a) (PAGES 2k Consortium 2013). The warming trend of PAGES $2 \mathrm{~K}$ Asian summer MinT from 1820 to 1989 is $0.43 \pm 0.08{ }^{\circ} \mathrm{C} /$ century $\left(\mathrm{R}^{2}=0.41\right.$, $P<0.001$, thick red line in Fig. $8 \mathrm{a}$ ), a value very close to the $0.40 \pm 0.1{ }^{\circ} \mathrm{C} /$ century we calculated for the same period (thick black line in Fig. 8 b), or $0.45 \pm 0.09{ }^{\circ} \mathrm{C} /$ century for the interval 1820-2009. Ten TRW chronologies used in PAGES $2 \mathrm{~K}$ were produced in the general vicinity of our sampling region (black circles in Fig. 1). The PC1 of all 10 chronologies in Fig. 8c, shows no significant tend. The 30-year FFT low-pass filtered records of PC1 $\left(\mathrm{PC}_{10}\right)$, summer MinT of Southeast TP of this study $\left(\mathrm{MinT}_{\mathrm{TP}}\right)$ and Asian scale summer MinT from PAGES $2 \mathrm{k}$ project $\left(\mathrm{MinT}_{\mathrm{ASI}}\right)$ were normalized and compared in Fig. 8d. $\operatorname{MinT}_{\mathrm{TP}}$ and $\mathrm{MinT}_{\mathrm{ASI}}$ show common multi-decadal variability before the 1920 s, while after the 1920 s MinT $_{\mathrm{TP}}$ exhibits larger variability. Tibetan ice core $\delta^{18} \mathrm{O}$ data suggests that a TP-scale warming started around the 1800s (Thompson et al. 2006). TP temperature reconstructions based on alpine treelines show various dates of recent warming: in northern TP the last warming started around the 1820s (Zhu et al. 2008), while in the southern Himalayas the last warming started in the 1890s (Yadav et al. 2011). The Asia 2K sub project of PAGES $2 \mathrm{~K}$ concluded that the last whole Asian warming started around the 1820s, and the 1990s was the warmest decade in last 1,200 years (Cook et al. 2013). Despite some agreement between $\mathrm{PC}_{10}$ and $\mathrm{MinT}_{\mathrm{ASI}}$ at the multidecadal scale, $\mathrm{PC}_{10}$ does not show any centennial trend especially after nineteenth century (Fig. 8d). Among the 10 chronologies, Asi_38 to Asi_42 were originally used to reconstruct Asian summer monsoon history (Cook et al. 2010), and chronologies Asi_79 to Asi_83 were first published for regional spring PDSI (Palmer Drought Severity Index) reconstruction (Fan et al. 2008). We may reasonably assume that these samples are collected below the Alpine treelines, where tree growth may not be sensitive to longterm temperature variability, which could lead to inconsistencies between their and our trends.

\section{Comparison with CMIP5 historical simulations}

If the warming trend is a simple, linear response to external forcings, one would expect it to be captured in ensemble climate model simulations. For instance, recent detection/ attribution studies have identified an externally forced signal in European summer temperatures (Hegerl et al. 2011). This is also hinted at by some consistency between PAGES $2 \mathrm{k}$ continental reconstructions and CMIP5 last millennium simulations (PAGES 2k Consortium 2013; Section 5.5 and Figure 5.12 in IPCC AR5, WG1, 2013). Figure 9 shows the multi-model average MinT for our studied area, based on CMIP5 historical simulations (Chapter 12 in IPCC AR5, WG1, 2013 available at the KNMI website: http://www.k nmi.nl/). The multi-model ensemble mean shows no significant trend prior to the last decades of the twentieth century, where it reaches $0.23 \pm 0.05{ }^{\circ} \mathrm{C} /$ decade $(P<0.001)$ between 1973 and 2003. This warming rate is lower than those calculated from our data $\left(0.41 \pm 0.13{ }^{\circ} \mathrm{C} /\right.$ decade $)$ and from the CRU data $\left(0.37 \pm 0.24^{\circ} \mathrm{C} /\right.$ decade $)$ during the same period. If the ensemble mean of climate models perfectly captured the response of TP climate to anthropogenic forcing, the rate difference between data and model implies that anthropogenic forcing only accounted for about $60 \%$ of the observed warming during this period. The remainder may be potentially forced by multi-decadal factors represented by AMO variability, or other sources of uncertainties arising from an incorrect representation of regional forcing factors such as anthropogenic aerosols. Climate models do not simulate the centennial warming trend of reconstruction. Moreover, they underestimate the magnitude of multi-decadal variability, and the magnitude of the recent warming trend.

\section{Summary and discussion}

The common signal (PC1) extracted from all our tree ring width chronologies is strongly related to regional summer MinT at the inter-annual scale and with respect to recent trends. Some TRW chronologies display weak climatic significance and decreasing trends due to inevitable local environmental effects other than temperature. This highlights the importance of appropriate sampling strategy and the collection of sufficient source chronologies in order to reliably extract long-term regional climate signals. The close link between summer MinT and tree growth pattern 
Fig. 8 a Asian summer (JJA) minimum temperature of PAGES 2k project (thin black line) and trend from 1820 to 1989 (thick red line); b Southeast TP summer (JJA) minimum temperature reconstruction of this study (thin black line) and trend from 1820 to 1989 (thick black line); c Leading principal component of the ten chronologies used in PAGE 2k project near our study region (thin black line). Thick curves of red, black and blue in Fig. 8a-c are 30 years fast fourier transform (FFT) low pass filtered trends; d normalized trends shown in Fig. 8a-c

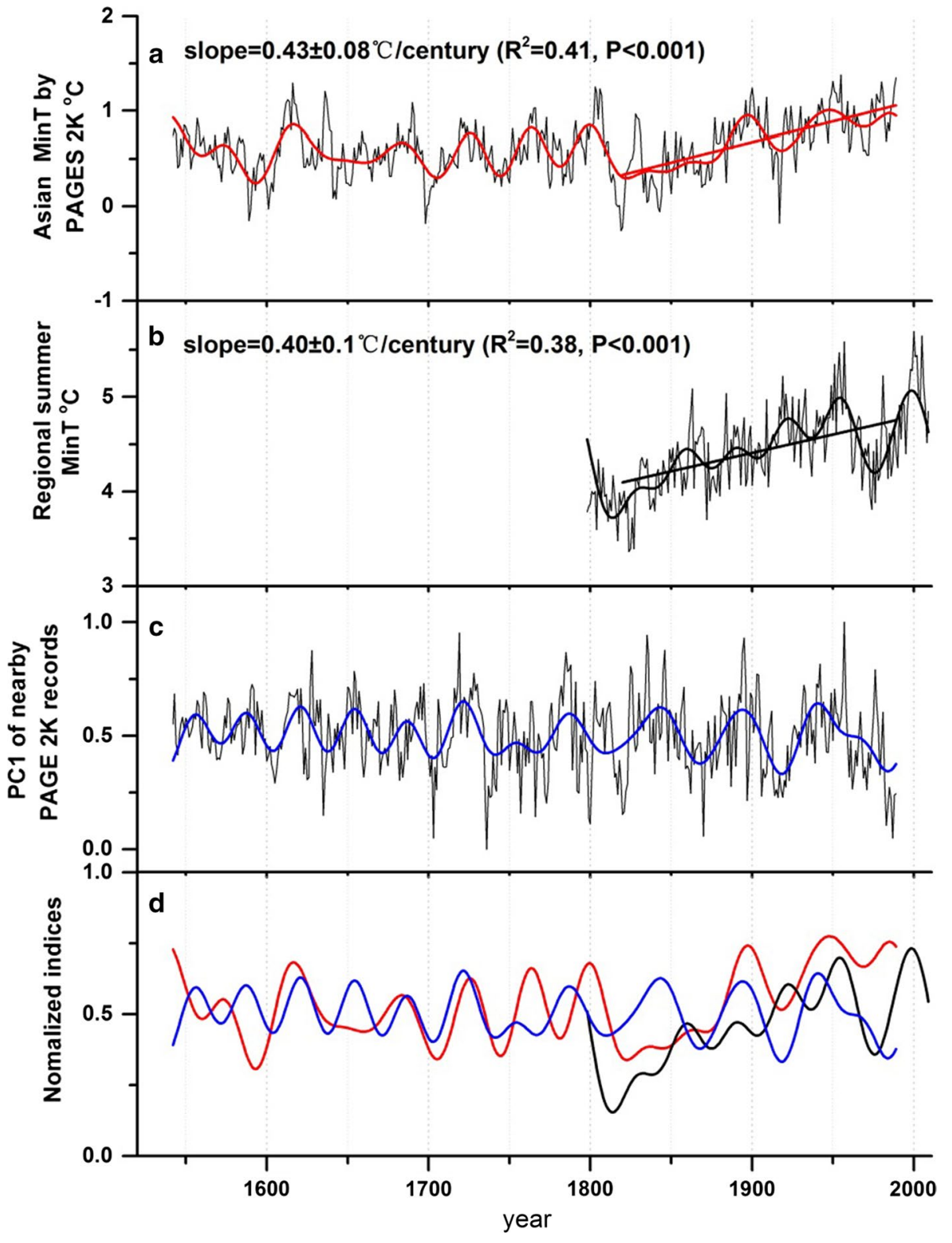

on southeast TP suggests that summer night temperature is the key for xylogenesis and radial growth, which supports the theory of night temperature control on tree growth at Alpine treelines (Korner 1998; Hoch and Korner 2003). Assuming that moisture availability will not be a limiting factor in the future, these observations suggest an overall increase in tree growth on the southeast TP in response to future warming.

Our reconstruction reveals a centennial long-term summer MinT increase since the 1820 s, which is consistent with the results of similar studies conducted in the northern TP (Zhu et al. 2008) and whole TP (ice-core based temperature reconstruction; Thompson et al. 2006). The warming rates in our reconstruction are also consistent with those of Asian summer MinT reconstructed by the PAGES 2k project. However, no such trend emerges from the 10 chronologies used by PAGES $2 \mathrm{k}$ from near our study region because these data were collected below Alpine treeline and more controlled by moisture variability (Cook et al. 2010; Fan et al. 2008) rather than by temperature.

Our reconstruction shows an enhanced decadal variability as well as more frequent cold and warm extremes during the last 6 decades, with the warming amplitude larger than the total summer MinT warming in last 200 years. There is an ambiguous coherence between our warm/cold intervals and those of the AMO, partly supporting earlier studies focused on northeast China and southeast TP (Wang et al. 2011, b). CMIP5 historical simulations only produce a warming trend since 1970 s, with a magnitude $40 \%$ lower than the increase recorded in instrumental data and in our 
Fig. 9 Comparison of reconstructed MinT and historical regional MinT outputs of $(\mathrm{N}$ 28-33, E $98-103^{\circ}$ ) models from CMIP5

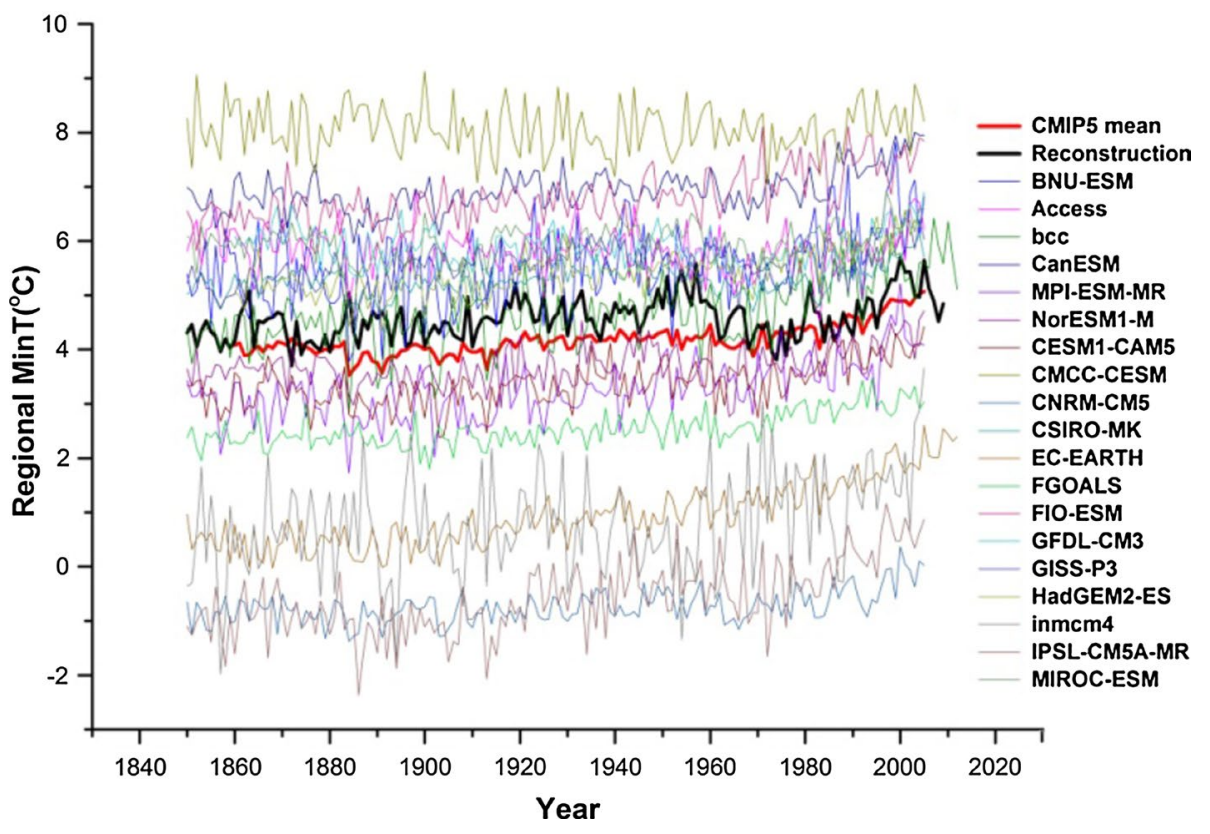

reconstruction during the same interval. None of the individual simulation available in CMIP5 is able to capture the magnitude of the observed and reconstructed decadal TP summer temperature variability which may have contributed to the recent observed warming. Our reconstruction also depicts a centennial warming trend, which is not reproduced in CMIP5 historical simulations. This finding may have profound implications for the use of climate projections in guiding adaptation strategies, as non-greenhouse forcing or natural variability can induce strong deviations, at the decadal to multi-decadal scales, from model simulations.

Acknowledgments We thank Forestry Department of Sichuan Province, Forestry Administrations of Ganzi Zhou and all counties we sampled for the great helps in field work. The field work was supported by the grant from State Key Laboratory on Earth Surface Processes and Resource Ecology, code: 270403GK. We thank Prof. Ruijie LU and Qijing LIU for providing Lintab ${ }^{\circledR}$ system. We are grateful for the generous help of Duoying JI, Qian MA, Yong LIANG and Jiangzheng WU in terms of data processing and fieldwork assistance. KNMI climate explorer has largely facilitated the processing of CRU and CMIP5 data.

\section{References}

Bindoff NL, Stott PA, AchutaRao KM, Allen MR, Gillett N, Gutzler D, Hansingo K, Hegerl G, Hu Y, Jain S, Mokhov II, Overland J, Perlwitz J, Sebbari R, Zhang X (2013) Detection and attribution of climate change: from global to regional. In: Stocker TF, Qin D, Plattner GK, Tignor M, Allen SK, Boschung J, Nauels A, Xia Y, Bex V, Midgley PM (eds) Climate change 2013: the physical science basis. Contribution of working group I to the fifth assessment report of the intergovernmental panel on climate change. Cambridge University Press, Cambridge
Biondi F, Waikul K (2004) DENDROCLIM2002: a C++ program for statistical calibration of climate signals in tree-ring chronologies. Comput Geosci UK 30:303-311

Briffa KR, Melvin TM (2011) A closer look at regional curve standardization of tree-ring records: justification of the need, a warning of some pitfalls, and suggested improvements in its application. In: Hughes MK, Swetnam TW, Diaz HF (eds) Dendroclimatology. Progress and prospects. Springer, New York

Briffa KR, Jones PD, Bartholin TS, Eckstein D, Schweingruber FH, Karlen W, Zetterberg P, Eronen M (1992) Fennoscandian summers from $\mathrm{AD} 500$ : temperature changes on short and long timescales. Clim Dyn 7:111-119

Briffa KR, Schweingruber FH, Jones PD, Osborn TJ, Shiyatov SG, Vaganov EA (1998) Reduced sensitivity of recent treegrowth to temperature at high northern latitudes. Nature 391: 678-682

Briffa KR, Osborn TJ, Schweingruber FH, Harris IC, Jones PD, Shiyatov SG, Vaganov EA (2001) Low-frequency temperature variations from a northern tree ring density network. J Geophys Res 106:2929-2941

Briffa KR, Osborn TJ, Schweingruber FH (2004) Large-scale temperature inferences from tree rings: a review. Global Planet Change 40:11-26

Cao JX, Chen Z, Shang H, Lin B (2012) Tree-ring based average June-July temperature reconstruction for Siguniang Mountains of West Sichuan Plateau, China. J Food Agric Environ 10:1341-1345

Chen B, Chao WC, Liu X (2003) Enhanced climatic warming in the Tibetan Plateau due to doubling $\mathrm{CO}_{2}$ : a model study. Clim Dyn 20:401-413

Collins M, Knutti R, Arblaster J, Dufresne JL, Fichefet T, Friedlingstein P, Gao X, Gutowski WJ, Johns T, Krinner G, Shongwe M, Tebaldi C, Weaver AJ, Wehner M (2013) Long-term climate change: projections, commitments and irreversibility. In: Stocker TF, Qin D, Plattner GK, Tignor M, Allen SK, Boschung J, Nauels A, Xia Y, Bex V, Midgley PM (eds) Climate change 2013: the physical science basis. Contribution of working group I to the fifth assessment report of the intergovernmental panel on climate change. Cambridge University Press, Cambridge 
Cook ER, Briffa KR, Meko DM, Graybill DA, Funkhouser G (1995) The segment length curse in long tree-ring chronology development for paleoclimatic studies. Holocene 5:229-237

Cook ER, Anchukaitis KJ, Buckley BM, D’Arrigo RD, Jacoby GC, Wright WE (2010) Asian monsoon failure and megadrought during the last millennium. Science 328:486-489

Cook ER, Krusic PJ, Anchukaitis KJ, Buckley BM, Nakatsuka T, Sano M (2013) Tree-ring reconstructed summer temperature anomalies for temperate East Asia since 800 CE. Clim Dyn 41:2957-2972

D'Arrigo R, Wilson R, Jacoby G (2006) On the long-term context for late twentieth century warming. J Geophys Res 111:D03103. doi: 10.1029/2005JD006352

Duan JP, Zhang QB, Lv LX, Zhang C (2012) Regional-scale winterspring temperature variability and chilling damage dynamics over the past two centuries in southeastern China. Clim Dyn 39:919-928

Esper J, Cook ER, Schweingruber FH (2002) Low-frequency signals in long tree-ring chronologies for reconstructing past temperature variability. Science 295:2250-2253

Esper J, Cook ER, Krusic PJ, Peters K, Schweingruber FH (2003) Tests of the RCS method for preserving low-frequency variability in long tree-ring chronologies. Tree Ring Res 59:81-98

Fajardo A, Piper FI, Hoch G (2013) Similar variation in carbon storage between deciduous and evergreen treeline species across elevational gradients. Ann Bot Lond 112:623-631

Fan ZX, Brauning A, Cao KF (2008) Tree-ring based drought reconstruction in the central Hengduan Mountains region (China) since AD 1655. Int J Climatol 28:1879-1887

Gao LL, Gou XH, Deng Y, Liu WH, Yang MX, Zhao ZQ (2013) Climate-growth analysis of Qilian juniper across an altitudinal gradient in the central Qilian Mountains, northwest China. Trees Struct Funct 27:379-388

He MH, Yang B, Datsenko NM (2013) A six hundred-year annual minimum temperature history for the central Tibetan Plateau derived from tree-ring width series. Clim Dyn. doi:10.1007/ s00382-013-1882-x

Hegerl G, Luterbacher J, Gonzalez-Rouco F, Tett S, Crowley T, Xoplaki E (2011) Influence of human and natural forcing on European seasonal temperatures. Nat Geosci 4:99-103

Hoch G, Korner C (2003) The carbon charging of pines at the climatic treeline: a global comparison. Oecologia 135:10-21

Hoch G, Popp M, Korner C (2002) Altitudinal increase of mobile carbon pools in Pinus cembra suggests sink limitation of growth at the Swiss treeline. Oikos 98:361-374

Holmes R (1983) Computer assisted quality control in tree-ring dating and measurement. Tree-Ring Bull 44:69-75

Jobbagy EG, Jackson RB (2000) Global controls of forest line elevation in the northern and southern hemispheres. Global Ecol Biogeogr 9:253-268

Kang SC, Xu YW, You QL, Flugel WA, Pepin N, Yao TD (2010) Review of climate and cryospheric change in the Tibetan Plateau. Environ Res lett 5:015101. doi:10.1088/1748-9326/5/1/015101

Knapp PA, Soule PT, Grissino-Mayer HD (2001) Detecting potential regional effects of increased atmospheric $\mathrm{CO}_{2}$ on growth rates of western juniper. Global Change Biol 7:903-917

Knutson TR, Zeng FR, Wittenberg AT (2013) Multimodel assessment of regional surface temperature trends: CMIP3 and CMIP5 twentieth-century simulations. J Clim 26:8709-8743

Korner C (1998) A re-assessment of high elevation treeline positions and their explanation. Oecologia 115:445-459

Korner C (2003) Carbon limitation in trees. J Ecol 91:4-17

Li ZS, Liu G, Zhang Q, Hu C, Luo S (2011) Tree ring-based summer temperature reconstruction over the Past 200 Years in Miyaluo of Western Sichuan China. Quat Sci (in Chinese with English abstract). doi:10.3969/j.issn.10017410.2011.0
Li XX, Liang EY, Gricar J, Prislan P, Rossi S, Cufar K (2013) Age dependence of xylogenesis and its climatic sensitivity in Smith fir on the south-eastern Tibetan Plateau. Tree Physiol 33:48-56

Liang EY, Shao XM, Qin NS (2008) Tree-ring based summer temperature reconstruction for the source region of the Yangtze River on the Tibetan Plateau. Global Planet Change 61:313-320

Liang EY, Shao XM, Xu Y (2009) Tree-ring evidence of recent abnormal warming on the southeast Tibetan Plateau. Theor Appl Climatol 98:9-18

Liang EY, Wang YF, Eckstein D, Luo TX (2011) Little change in the fir tree-line position on the southeastern Tibetan Plateau after 200 years of warming. New Phytol 190:760-769

Liu XD, Chen BD (2000) Climatic warming in the Tibetan Plateau during recent decades. Int J Climatol 20:1729-1742

Ljungqvist FC, Krusic PJ, Brattstrom G, Sundqvist HS (2012) Northern Hemisphere temperature patterns in the last 12 centuries. Clim Past 8:227-249

Lv LX, Zhang QB (2013) Tree-ring based summer minimum temperature reconstruction for the southern edge of the Qinghai-Tibetan Plateau, China. Clim Res 56:91-101

Makinen H, Nojd P, Kahle HP, Neumann U, Tveite B, Mielikainen K, Rohle H, Spiecker H (2002) Radial growth variation of Norway spruce (Picea abies (L.) Karst.) across latitudinal and altitudinal gradients in central and northern Europe. For Ecol Manag 171:243-259

Manabe S, Broccoli AJ (1990) Mountains and arid climates of middle latitudes. Science 247:192-194

Masson-Delmotte V, Schulz M, Abe-Ouchi A, Beer J, Ganopolski A, González Rouco JF, Jansen E, Lambeck K, Luterbacher J, Naish T, Osborn T, Otto-Bliesner B, Quinn T, Ramesh R, Rojas M, Shao X, Timmermann A (2013) Information from paleoclimate archives. In: Stocker TF, Qin D, Plattner GK, Tignor M, Allen SK, Boschung J, Nauels A, Xia Y, Bex V, Midgley PM (eds) Climate change 2013: the physical science basis. Contribution of working group I to the fifth assessment report of the intergovernmental panel on climate change. Cambridge University Press, Cambridge

Melvin TM, Briffa KR (2014) CRUST: software for the implementation of Regional Chronology Standardisation: Part 1. Signal-Free RCS. Dendrochronologia 32:7-20

Norby RJ et al (2005) Forest response to elevated $\mathrm{CO}_{2}$ is conserved across a broad range of productivity. Proc Natl Acad Sci USA 102:18052-18056

Oerlemans J (2005) Extracting a climate signal from 169 glacier records. Science 308:675-677

PAGES 2k Consortium (2013) Continental-scale temperature variability during the past two millennia. Nat Geosci 6:339-346

Piao SL, Ciais P, Huang Y, Shen ZH, Peng SS, Li JS, Zhou LP, Liu HY, Ma YC, Ding YH, Friedlingstein P, Liu CZ, Tan K, Yu YQ, Zhang TY, Fang JY (2010) The impacts of climate change on water resources and agriculture in China. Nature 467:43-51

Qin J, Yang K, Liang SL, Guo XF (2009) The altitudinal dependence of recent rapid warming over the Tibetan Plateau. Clim Change 97:321-327

Rossi S, Deslauriers A, Anfodillo T, Carraro V (2007) Evidence of threshold temperatures for xylogenesis in conifers at high altitudes. Oecologia 152:1-12

Rossi S, Deslauriers A, Anfodillo T, Carrer M (2008a) Age-dependent xylogenesis in timberline conifers. New Phytol 177:199-208

Rossi S, Deslauriers A, Gricar J, Seo JW, Rathgeber C, Anfodillo T, Morin H, Levanic T, Oven P, Jalkanen R (2008b) Critical temperatures for xylogenesis in conifers of cold climates. Global Ecol Biogeogr 17:696-707

Salzer MW, Hughes MK, Bunn AG, Kipfmueller KF (2009) Recent unprecedented tree-ring growth in bristlecone pine at the highest elevations and possible causes. Proc Natl Acad Sci USA 106:20348-20353 
Saxe H, Ellsworth DS, Heath J (1998) Tree and forest functioning in an enriched $\mathrm{CO}_{2}$ atmosphere. New Phytol 139:395-436

Shi CM, Masson-Delmotte V, Daux V, Li ZS, Zhang QB (2010) An unstable tree-growth response to climate in two 500 year chronologies, North Eastern Qinghai-Tibetan Plateau. Dendrochronologia 28:225-237

Sun JQ, Wang HJ, Yuan W (2008) Decadal variations of the relationship between the summer North Atlantic Oscillation and middle East Asian air temperature. J Geophys Res 113:D15107. doi:10. 1029/2007JD009626

Sutton RT, Dong BW (2012) Atlantic Ocean influence on a shift in European climate in the 1990s. Nat Geosci 5:788-792

Sutton RT, Hodson D (2005) Atlantic Ocean forcing of North American and European summer climate. Science 309:115-118

Swidrak I, Gruber A, Kofler W, Oberhuber W (2011) Effects of environmental conditions on onset of xylem growth in Pinus sylvestris under drought. Tree Physiol 31:483-493

Thebault A, Clement JC, Ibanez S, Roy J, Geremia RA, Perez CA, Buttler A, Estienne Y, Lavorel S (2014) Nitrogen limitation and microbial diversity at the treeline. Oikos 123:729-740

Thompson LG, Yao T, Davis ME, Henderson KA, MosleyThompson E, Lin PN, Beer J, Synal HA, ColeDai J, Bolzan JF (1997) Tropical climate instability: the last glacial cycle from a QinghaiTibetan ice core. Science 276:1821-1825

Thompson LG, Mosley-Thompson E, Brecher H, Davis M, Leon B, Les D, Lin PN, Mashiotta T, Mountain K (2006) Abrupt tropical climate change: past and present. Proc Natl Acad Sci USA 103:10536-10543

van Oldenborgh GJ, Te Raa LA, Dijkstra HA, Philip SY (2009) Frequency- or amplitude-dependent effects of the Atlantic meridional overturning on the tropical Pacific Ocean. Ocean Sci 5:293-301

Wang B, Linho (2002) Rainy season of the Asian-Pacific summer monsoon. J Climate 15:386-398

Wang B, Bao Q, Hoskins B, Wu GX, Liu YM (2008) Tibetan plateau warming and precipitation changes in East Asia. Geophys Res Lett 35:L14702. doi:10.1029/2008GL034330

Wang XC, Brown PM, Zhang YN, Song LP (2011) Imprint of the Atlantic multidecadal oscillation on tree-ring widths in Northeastern Asia since 1568. PLoS ONE 6:e22740. doi:10.1371/ journal.pone.0022740

Wang JL, Yang B, Ljungqvist FC, Zhao Y (2013a) The relationship between the Atlantic Multidecadal Oscillation and temperature variability in China during the last millennium. J Quat Sci 28:653-658

Wang JL, Yang B, Qin C, Kang SY, He MY, Wang ZY (2013b) Treering inferred annual mean temperature variations on the southeastern Tibetan Plateau during the last millennium and their relationships with the Atlantic multidecadal oscillation. Clim Dyn. doi:10.1007/s00382-013-1802-0

Wang X, Siegert F, Zhou AG, Franke J (2013c) Glacier and glacial lake changes and their relationship in the context of climate change, Central Tibetan Plateau 1972-2010. Global Planet Change 111:246-257

Wei YQ, Fang YP (2013) Spatio-temporal characteristics of global warming in the Tibetan Plateau during the last 50 years based on a generalised temperature zone-elevation model. PLoS ONE 8:e60044. doi:10.1371/journal.pone.0060044

Wilmking M, Juday GP, Barber VA, Zald H (2004) Recent climate warming forces contrasting growth responses of white spruce at treeline in Alaska through temperature thresholds. Global Change Biol 10:1724-1736

Yadav RR, Braeuning A, Singh J (2011) Tree ring inferred summer temperature variations over the last millennium in western Himalaya, India. Clim Dynam 36:1545-1554

Yang B, Kang XC, Liu JJ, Brauning A, Qin C (2010a) Annual temperature history in Southwest Tibet during the last 400 years recorded by tree rings. Int J Climatol 30:962-971

Yang B, Kang XC, Brauning A, Liu J, Qin C, Liu JJ (2010b) A 622year regional temperature history of southeast Tibet derived from tree rings. Holocene 20:181-190

Yang K, Wu H, Qin J, Lin CG, Tang WJ, Chen YY (2014) Recent climate changes over the Tibetan Plateau and their impacts on energy and water cycle: a review. Global Planet Change 112:79-91

Yao TD, Wang YQ, Liu SY, Pu JC, Shen YP, Lu AX (2004) Recent glacial retreat in High Asia in China and its impact on water resource in Northwest China. Sci China Ser D 47:1065-1075

Yao TD, Thompson L, Yang W, Yu WS, Gao Y, Guo XJ, Yang XX, Duan KQ, Zhao HB, Xu BQ, Pu JC, Lu AX, Xiang Y, Kattel DB, Joswiak D (2012) Different glacier status with atmospheric circulations in Tibetan Plateau and surroundings. Nat Clim Change 2:663-667

Yao TD, Masson-Delmotte V, Gao J, Yu WS, Yang XX, Risi C, Sturm C, Werner M, Zhao HB, He Y, Ren W, Tian LD, Shi CM, Hou SG (2013) A review of climatic controls on delta O-18 in precipitation over the Tibetan Plateau: observations and simulations. Rev Geophys 51. doi:10.1002/rog.20023

Zhang YX, Wilmking M (2010) Divergent growth responses and increasing temperature limitation of Qinghai spruce growth along an elevation gradient at the northeast Tibet Plateau. For Ecol Manag 260:1076-1082

Zhu HF, Zheng YH, Shao XM, Liu XH, Xu Y, Liang EY (2008) Millennial temperature reconstruction based on tree-ring widths of Qilian juniper from Wulan, Qinghai Province, China. Chin Sci Bull 53:3914-3920 